Economic behaviour as leitmotiv in health policy in Germany and its consequences for prevention and health promotion

\title{
O agir econômico como motor da política de saúde na Alemanha: consequências para a prevenção e promoção da saúde
}

Klaus Stegmüller ${ }^{1}$

\footnotetext{
${ }^{1}$ Department Nursing and Health Sciences, University of Applied Sciences Fulda. Marquardstr. 35, D-36039 Fulda.

stegmueller@hs-fulda.de
}

Abstract Since the mid 1970s the health policy in Germany has focused on cost containment - pre cisely reduction of employer's contribution for statutory health insurance (SHI). However political parties and the government have also changed their strategies to achieve this aim. The grown structures of SHI concerned with financing, provision and management remained unaltered till the early $90 \mathrm{~s}$. The 90 s are marked by a broad transformation of the health sector. Regulatory instruments have been developed to create financial incentives for all stakeholders ( sickness funds, health care providers, insured/patients) to reduce expenditure in health sector. The transformation process is marked by normative principle of taking stakeholders as economic subjects acting rationally. The article aims at evaluating the desi red/undesi red impacts of thisparadigm shift, where solidarity is surpassed by competition, co-payment and privatisation. It shows where this paradigm change can be observed and which instruments have been used for its realisation. It is also given an analysis on the reaction of important stakeholders to this change. Finally, it is demonstrated ,by using examples of prevention and health promotion that the only focus on economic models doesn't allow health policy to adequately meet the challenges set upon it.

Key words Health policy, Economic behaviour, Privatisation, Commercialisation, Prevention and health promotion policies
Resumo Desde os anos setenta, a política de saúde alemã se concentrou na contenção de custos - mais precisamente, na redução da contribuição do empregador para o seguro de saúde estatutário (SHI). As estruturas expandi das do $\mathrm{SHI}$ relacionadas ao financiamento, provisão e gerenciamento permaneceram inalteradas até o início dos anos noventa. Porém, o período seguinte foi marcado por ampla transformação. Desenvolveram-se instrumentos regulatórios para criar incentivos financeiros a fundos de saúde, fornecedores de assi stência médica e segurados/pacientes para reduzir os gastos. Essa transformação baseou-se no princípio normativo, que considera osinteressados como sujeitos econômicos agindo de forma racional. 0 objetivo deste trabalho é avaliar os impactos desejadosenão desejados deuma mudança de paradigma, em que a solidariedade é sobrepujada pela competição, co-pagamento e privatização. M ostra-se onde essa mudança paradigmática pode ser vista e os instrumentos usados para que se realizasse. Em seguida, analisam-seas reações dosfundos de saúde, provedores deassistência médica e segurados/pacientes a essa mudança. Por fim, demonstra-se, com exemplos de prevenção e promoção de saúde, que o foco exclusi vo neste modelo econômico não permite que a política de saúde realize adequadamente seus objetivos.

Palavras-chave Política de saúde, Comportamento econômico, Privatização, Comercialização, Políticas de promoção de saúde e prevenção 
The Health Care System in Germany a short introduction ${ }^{1}$

Healthcare in Germany is funded by a statutory contribution system that ensures free healthcare for all via sickness funds. Insurance payments are based on a percentage of income, nearly half divided between employee and employer. Healthcare insurance in Germany is divided between statutory and private schemes. The statutory health insurance (SHI), the so-called "GesetzlicheKrankenversicherung" (GKV), occupies a central position in the healthcare system in the Federal Republic of Germany. About $88 \%$ of the population are covered by thestatutory health insurance which iscompulsory for all who earn less than approx. 4.050 per month (in 2009) before tax. Private healthcare schemes can either provideto complete health service for those who opt out for the SHI (10\%) or top-up cover for those who remain within it. $2 \%$ were covered by governmental schemes and $0.2 \%$ were not covered by any third-party-payer scheme.

The health care system has a decentralized organisation, characterized by federalism and delegation to nongovernmental corporatist bodies as the main actors in the social health insurance system: the physicians' and dentists' associations on the providers' sideand the sickness funds and their associations on the purchasers' side. The provision of healthcarein Germany, which can be broadly separated into ambulatory and in patient sectors, is guaranteed by a large number of institutions and persons who contribute to promote, maintain and restore the health of the population. O utpatient services supplied to the public are largely the responsibility of independent doctors practising on a freelance basis under contract to the $\mathrm{SH}$. Doctors caring for patients who havesickness funds must be registered by law by the regional association of SHI Physicians. Each of the 16 states ("Bundesländer") shareresponsibility with thecentral government for thehospitals and clinics, while theSHI providers exert somecontrol over running costs.

The M inistry of $\mathrm{H}$ ealth and Social Security proposes the health acts that - when passed by parliament - define the legislative framework of the SH I system. It also supervises the corporatist bodies and - with the assistance of a number of subordinate authorities - fulfils various licensing and supervisory functions, performs scientific consultancy work and provides information services. About 202 (in 2009) sickness funds collect contributions, and purchase proactively or pay retroactively for health and long-term care services for members.
Since 1996 almost every insured person has the right to choose a sickness fund freely, while funds are obliged to accept any applicant.

In international comparison, the German health care system has a high level of financial resources and physical capacities. The population enjoys equal and easy access to a health care system offering a comprehensive benefits package at all levels of care; waiting lists and explicit rationing decisions are virtually unknown until now. There is doubt, however, whether the high and growing spending on health translates into a sufficiently cost-efficient use of resources. Therefore the government had initiated a transformation process, which is marked by normative principles of taking all stakeholders as subjects acting mere economically, by intensifying competition among them and by implementing co-payment and privatisation.

Health care reforms: paradigm shift in health policy and its instruments

Since mid 1970s health policy in Germany can be divided into two distinct phases: phase 1 (19721993) is marked by policy measures aiming at costcontainment without changing the structures in $\mathrm{SHI}$, whereas phase 2 starting with the enactment of $\mathrm{H}$ ealth Sector Act of 1993 (GSG) and continuing till date is manifested by structure reforms introducing competition in health insurancemarket and privatisation.

\section{Traditional cost-containment policy}

The traditional cost-containment policy in the first phase laid emphasis on the involvement of associations in efforts to reduce costs ${ }^{2}$ and brought only moderate changes in the regulatory architecture of $\mathrm{SHI}^{3}$. However, the historically grown structures of $\mathrm{SHI}$ concerned with financing, provision and management remained much the same. The created incentives (i.e. moderate co-payment, not very rigorous budgets) were not so strong that they could effectively stimulatethem to constraint the delivery, financing or utilisation of the health services.

Paradigm shift:

financial incentives and competition

The enactment of the Health Sector Act of 1993 initiated the paradigm shift in German health policy ${ }^{4}$ to reach cost-containment in anew quality and with new instruments. A transformation process 
was instituted which to date continues ${ }^{5}$. In the course of this transformation process, the financial regulatory instruments have been consistently amplified. The German government applied the following instruments to strongly modify the incentives for action among the stakeholders:

.The implementation of freechoice of sickness fund for the insured considerably provoked competition in SHI since 1993. Sickness funds competed, first, on the basis of their contribution rates with one another for members.

. Adaption of lump-sums and individual budgets as mechanisms for reimbursement of the health services shifted the financial risk towards health care providers.

. Patients have been forced to pay elevated copayments. There is a clear trend towards privatisation of the health care costs as is evident in launching possibilities of different optional tariffs, deductions and contribution refund for the insured.

. Sickness funds can now make selective contracts with health care providers and the dominating collective contracts are gradually losing their importance.

. And finally: Therecent health-care reform act (SHI-Competition Strengthening Act, SHI-CSA), established in 2009, introduces several measures that will change the institutional arrangements of health care financing in Germany fundamentally. The design of regulated competition in the $\mathrm{SHI}$ is altered by establishing a Federal $\mathrm{H}$ ealth Insurance Fund, an unitary contribution rate and elements of a morbidity based risk-adjustment mechanism, while competition is finally implemented into the system of Private $\mathrm{H}$ ealth Insurance (PHI). Thereby, the government aims at intensifying competition in the German health care system in order to improveitseconomic efficiency. H owever, theSHICSA will have contradictory effects on both the functioning of competition and the foundations of solidarity within the German health care system. Firstly, theintensification of competition within theSH I will not sweep away economic incentives for cream skimming by sickness funds. Secondly, theconvergence of regulating $\mathrm{SHI}$ and $\mathrm{PHI}$ will also make cream skimming a common strategy among sickness funds and private health insurance companies, competing both for the healthy, wealthy and young.

The German health policy has conceived all stakeholders as economic subjects acting rationally and tries to integrate them into a system of financial incentives and competition.
The ideology of competition

and financial incentives

The dominant interpretation among neo-liberal oriented policy-makers and scientists in Germany is based on the following assumptions:

a) The implementation of competition and financial incentives will orient both sickness funds and health care providers towards an efficient and high-quality health care. The behavioural incentives developed within historically grown regulatory system of $\mathrm{SHI}$ have been challenged, as they, from the point of view of economic rational behaviour, gave rise to counterproductive effects: in case of health care providers, the prevailing rei $\mathrm{m}$ bursement mechanisms encouraged the provision of unnecessary care; in case of the sickness funds, the strict allocation of the members ensured the sickness funds an ineffective existenceguarantee.

b) In the presence of free access to health care as the SHI guarantees the insured/patients lacked any incentives to narrow down the utilisation of health careservices. According to theso called "moral hazard"-theorem it is argued: While the insured cannot influence the extent of its insurance contribution, he has the incentive to raise his individual utility of health care services and he has an interest to recoup the individual costs incurred to him through "overutilisation" to the disadvantage of all members and society.

c) This theorem is based on another assumption: demand for health services is "price elastic", i.e. demand decreases with increased cost-participation and vice-versa. In this point of view copayments and privatisation are important for two reasons: Firstly, they motivate patients to use only those health services which are necessary; and secondly, to prompt them to adapt a health conscious behaviour to reduce the probability of a later utilisation of health care. In view of the supporters of this proposition, the volume of co-payments reached and level of privatisation in early 1990s was not sufficient enough to motivate the insured to reduce the utilisation of services to a considerable extent.

However, this paradigm shift incorporates farreaching consequences for the stakeholders. For the sickness funds the contribution rate in the presence of a uniform benefit catal ogue is the only crucial parameter in competing for members. Any increase in contribution rate is compounded with the imminent probability of losing market share. The introduction of capitation payment has profoundly changed financial incentives for health care providers. In case of capitation payment, the pro- 
viders can increase their income not through an overprovision of services but only through reducing the services brought per treatment case. The extent of the profit now lies in the difference between a priori fixed payment for thetreatment and the costs incurred actually. H ence, this kind of provider payment creates incentives to reduce the services brought per patient. Patients must now increasingly participatein the costs incurred for their health care (privatisation); the insured see themselves confronted with the requirement to move themselves as sovereign demanders in insurance market to search for best available offers for themselves (commercialisation).

\section{Behavioural expectations and - patterns}

The competition system and the financial incentives are very strong in their impact. The exit option for theinsured threatens sickness funds with a decrease in their income, organisational dismissals (e.g. discharge of staff, closing branch offices) and perhaps even insolvency. The incentive system directs the behaviour of health care providers to maximize their profits and reduce their losses. Hence, those who are not able to keep up in this competition should count with serious economic disadvantages. Therefore, patients and insured find them amidst stakeholders who follow strong financial self-interests in health care.

The advocates of this competition and incentive system argueas follows: It let looses the potentials of stakeholders to improve health care and health insurance products continually. It is not sufficient aloneto offer good solutions; rather success in health insurance market is measured on the basis whether a stakeholder can provide better solutions than the competitors. As a result, competition would lead to an economisation of and enhanced efficiency in health care with a simultaneous improvement in the quality of care ("quality competition"). In this way competition acts as a mechanism to continually improve problem-solving strategies which, otherwise, could not be developed - as Hayek ${ }^{6}$ says a "discovery process". The patients - according to the undertaking - would be the gainer in this new regulatory system, whilethey will benefit from theimproved quality and (as competition leads to) development of health care and insurance products which better fulfill the specific health care needs of the individuals.

The assumption that financial incentives can stimulate to raise efficiency in health care is, in the first instance, quite plausible. There are also con- stellations possiblein which profit-orientation and quality improvement can be synchronized. Certainly, on one hand the increase in profit and improvement in the quality of care on the other hand are two different goals which follow different logics to act. The improvement in qual ity could not be the most compelling reaction. $N$ ot only sickness funds but also health care provider can react quite alternatively. Hence, in an attempt to follow economic interests, the quality of the care could be reduced, adherence to quality standards could be faked, or quality failure could be concealed. However, an inversion of the principle of adequacy is also possible. Increase in profit and improving competition among the sickness funds are likely to becomethereal goals of the action of stakeholders.

\section{Sickness funds}

Asis well known, competition generates incentives for sickness funds to select risks. Although the risk compensation mechanism, which is a financial redistribution mechanism between sickness funds which equalizes the financial risks of the sickness funds with bad risk-profiles, introduced in 1993 should impede this behaviour, till 2008 it has not considered the morbidity of the insured as a parameter for compensation. H ence, the competition directed itself only at healthy and wealthy insured. In contrast, the chronically-ill insured, as they cause mores costs for sickness funds, built no attractiveclientagefor them. Whilemost expensive one fifth of the insured causes almost $80 \%$ of the total expenditure ${ }^{7}$, sickness funds had theincentive to reduce share of so called "bad risks" in their risk-pool. Indeed, sickness funds obstructed the development of modern health care structures directed at the particular health needs of the chronically-ill insured. Although theinsured can now freely choose their sickness fund and sickness funds cannot turn away potential enrollees, risk selection strategiesarestill in practice ${ }^{8}$. For example, through selectively placed advertisement, selectiveinvitations to switch, special offers for "good risks", inconveniences for undesirable insured, difference in the quality of service etc. Such strategies for risk selection are also common in other health care systems which have introduced competition among sickness funds $s^{9,10}$.

Theintroduction of selective contracts between singlesickness funds and single health care providers as a supplement to the so far dominating collective contracts extends the possibility for sickness funds to refuse those health care providers who deliver either low quality health services or unnec- 
essary medical care. M eanwhile, selective contracts have been realised in different health care areas: Examples are gate-keeper models, integrated care, and disease management programs. Since mid 1990sthis corresponding optionsfor sickness funds and health care providers have been continuously extended, but these new health care forms represent only a small segment of entire panorama of health delivery ${ }^{11}$. However, an extensive evaluation didn't took place until now; it is to be apprehensive for example of quality loss, rationing and cream skimming.

\section{Health care providers}

Since first half of 1990s such reimbursement mechanisms have been introduced which set incentives for physicians and hospitals to reduceand restrict the quantity of their services. Themost important instruments are capitation payment and budgets. Theimplementation of theseinstruments is based on the experience that physicians, in the absence of fixed expenditurelimitations, inclineto expand arbitrarily the volume of diagnostics and therapy. The fundamental problem with these reimbursement mechanisms lies in the fact that they are oriented on the stability of the contribution rate and not on the actual medical or health care needs. Furthermore, these reimbursement mechanisms cannot undertake that unnecessary services be excluded and only necessary services would be financed.

Such prospective reimbursement mechanisms facilitate rather delaying the treatments medically not justified, forwarding the patients in other health care institutions, and refraining to provide services. There are some clear indications that the application of these instruments leads to rationing of themedical care- deliberate but medically not justified refusal of services. In a survey of the insured by a large sickness fund, $27.4 \%$ of the respondents stated that they were refused to provide at least one service in the last quarter. Half of them were told that refusal is based in present financial limits. After having an insight into the patient data, the author came to the conclusion that it can be assumed in $10 \%$ of these cases with certainty that refused services would have been necessary from medical point of view ${ }^{12}$. Other studies also support these findings ${ }^{13}$. The refusal is particularly to be observed by prescription of drugs but also by treatments carried out by the physicians. In hospital sector, lump-sum payments lead among other to preterm discharge of patients, refusing the patients to accept for treatment, and to delay opera- tions ${ }^{14}$. The current implementation of Diagnostic Related Groups (DRGs) shows that economic considerations are becoming increasing significant in health car $^{15}$. There are clear indications of rationing in medical care, though reliable predictions about the extent of these practices, at this moment, cannot be made. It is also not clear whether lowincome individuals are strongly affected by these refusals. This assumption, socially neglected groups and individuals with low educational status are mostly refused services in health care practice services, is indeed plausible, as these individuals have meagre resources to articulate and enforce their needs effectively.

Insured and patients

Increase in co-payments and explicit exclusion of services from mandatory benefit catalogue are also the core instruments to contain costs in $\mathrm{SH}$. In year 1991, the volume of co-payments amounted to Euro 3.3 billion - corresponding to $4.4 \%$ of the expenditure in $\mathrm{SH} \mathrm{I}{ }^{16}$; with Euro 9.8 billion in 2002 they made $7.3 \%$ of theexpenditure. With the enactment of SHI-M odernisation Act (GKV-GM G) in 2004, which massively uplifted the existing and introduced new co-payments, the sum has once again appreciably increased. Alone co-payments for medicaments between 2003 and 2005 increased from 1.8 to 3.3 billion Euro which marks an uplift of $27 \%{ }^{17}$.

Co-payments can bring reduction in utilisation of health care services, when they are financially palpable. As this effect increases with decreasing incomes, co-payments affect predominantly financially weak population groups. Therefore, intended regulatory effect is inconsistent with social acceptability. This effect would be intensified by the fact that health risks and needs for treatment among the members of lower social classes lieusually above population average. Socially disadvantaged, in this way, would be quasi double punished. The redistribution mechanism embodied in solidarity principle would be also thereby weakened. Avoiding consultation with a doctor is likely to haveno negative effects on health, but it can lead to aggravation of the disease. The risk is greater by patients with bad health status who avoid consulting doctor even when it is medically imperative. This is reflected by RAND Health Insurance-Experiment which to date is the most comprehensive empirical analysis of the effects of cost-participation on the behaviour of the insured ${ }^{18}$. A part from that the study also showed that patients, whose utilisation of health services declined with increas- 
ing co-payments, avoided not only ineffective but also effective health services.

\section{Erosion of the solidarity system}

The privatisation of health care costs has been further amplified by the introduction of optional tariffs together with deductibles or contribution refund. Deductions and contribution refund imply a deep cut in the solidarity principle. The methods and principles common in private health insurance have found their way into SHI. They are especially attractive for young and healthy insured. In this way, financial resources are withdrawn from the solidarity-based SHI. Although these models do not directly affect the utilisation of services, they heavily burden persons with greater need for health care, as they have to bear up deficiencies in receipts without benefitting al onefrom optional tariffs. The solidarity based redistribution of the financial burden between healthy and sick in $\mathrm{SHI}$ is, as a result, limited and solidarity has been weakened.

The concept of financial incentives proceeds on the individual economic utilisation principle and egoistic rational behaviour. This rationality stands in contrast with the principle of solidarity which implies collective action in case of illness but without having the desire to achieve individual advantages. Sickness funds, so far, deemed as custodians of the idea of common bond in SHI. The competition required sicknessfunds, in order to realisetheir interests in broadening their entrepreneurial liberty, to useall possibilities to improvetheir individual market position. Thereby liberalisation of the privity of contract with health care providers and differentiations of contract conditions with theinsured and patients has taken centre stage in the action of sicknessfunds. With theenforcement of $\mathrm{H}$ ealth $\mathrm{C}$ are Act of 2007 (GKV-WSG) sickness funds can now offer a widerange of optional tariffs. They are making an intensive use of these optional tariffs, not least to win "good risks". The risk is growing that, with increased diffusion of optional tariffs and copayments, theinsured apprehend SHI no moreas a solidarity community, as they, due to privatisation of health risk, experienceless and less solidarity. The forced privatisation promotes the attitude to give priority to individual financial advantages.

In the following, using the example of health promotion and prevention, it would be demonstrated that health policy because of its strong orientation on economic rational behaviour, competition and privatisation cannot address core problems in health care adequately.
Prevention and health promotion

Prevention and health promotion count among the great challenges for health policy. The advocates of the abovementioned paradigm shift argue that strong privatisation of health costs also generates incentives to adapt a health conscious behaviour which would help avoiding future healthrelated costs. However, empirical substantive evidence for this correlation is not available. The present empirical knowledge base about the factors influencing health behaviour is rather against this proposition.

Health related behaviours (e.g. diet, physical activity, addictive behaviour) are expressions for and constituents of person-environment-arrangements of theindividual. They let them changehardly for long-term and cannot also be explained by the concept of "homo oeconomicus". Health is in life circumstances, at most, among others one of the targets but not the most significant. H azardous health behaviours endow a direct use normally for the individuals. In comparison, appearance of a disease as a result of these behaviours is mereIy an event possiblein future. The expectation that individuals abandon their hazardous health behaviour in view of future cost economisation is unreasonable. With regards to own health would here a cost-ben efit-principleimplied which doesnot exist in social reality. It does not mean that financial incentives aiming at behavioural change are anyway ineffective. Like lifting up the tobacco tax obviously achieved a regulatory effect. But themotive to modify behaviour in this case is different: It entails to avoid the costs incurred as a result of hazardous health behaviour, but not the costs for possible necessary treatments in future. Behaviour changesareonly possiblein theinteraction between life conditions, which depending upon social position offer the individual more or less scope, and opportunities contained within them to act ${ }^{19}$. Operating successful disease prevention and health promotion requires designing complex strategies which not only enhancehealth related resources of thehumans but also modify their lifeconditions in such a way that leads to permanent changes in their health behaviour ${ }^{20}$.

The appearance of disease can be only partially ascribed to the behaviour of the individual; at least alikesignificant are work-, environmental- and life conditions. Themembers of socially disadvantaged groups in the population, in particular, are mostly exposed to these adverse conditions, but at the same time have only few opportunities and resources availableto take influence on these conditions. The 
privatisation of the risk of ill-health changes nothing on the resources for action of these individuals, but rather burdens persons concerned with consequential-costs.

It can be assumed plausibly that financial incentives display, in fact, counterproductive effects. If a sickness fund finances preventive measures, it can be sure of only one thing: Prevention now and today causes expenditure. A possible financial benefit can beachieved, if at all, in many cases as recently as after long periods of time. Under the conditions of competition among the sickness funds and switching option for the insured, a sickness fund cannot be sure that whether it would benefit from possible cost saving in future though investments in prevention, or someother sicknessfund to whom the insured in the meanwhile has switched. With a view to economic benefit, prevention is characterised by an action in darkness. Therefore, economical competition is the major hurdle in the way of adequate consideration of prevention and health promotion through sickness funds ${ }^{21}$.

The health inequality can be primarily ascribed to the interaction between hard life circumstances and lifestyle. Thereis a consensusin health sciences over that a sustained reduction in health inequity can be most likely reached when interventions are restricted not only to change health related behaviour but also aim at changing life, work- and environment-conditions ("settings"). But creation of health promoting settings requires wide range and complex interventions. However, in Germany there has been developed only few innovative and pioneering practice models. In so far, the realisation of such intentions can be regarded as social innovation. The implementation of these efforts may also hit upon hurdles which can be replied by the innovation theory in social sciences ${ }^{22}$.

Furthermore, the conditions for success of social innovations arewell-acknowledged, as has been summarised by Everett Roger ${ }^{23}$ : The opportunities for success of an innovation increase with exceeding expected benefit, increased correlation with existing conditions, higher demonstrability of benefits, and low complexity of changes and vice versa. Applying these conditions for success to creating health promoting settings, it would be visible that their realisation is subject to great challenges.

\section{Benefit}

The strongest impetus to reduce health inequities, which can get political support over all discrepancies among stakeholders, is likely to be avoiding treatment costs in future. This goal can be most likely achieved, as one can argue, if measures for health promotion and prevention focus on those groups who are in most need of health care. However, this perception is sparsely reasonable, as in concrete terms reduction of health inequity can interfere with other interests. This can be depicted, particularly, by using the example of work environment. Enterprises, in many cases, follow their interests just by "exploiting" health of their employees and externalizing the consequential costs to the society. It indicates that the reduction of inequalities in health cannot be real ised, if theinterests of different stakeholders collide with each other.

\section{Compatibility}

The support for disease prevention and health promotion can be particularly mobilized, if they are commercialised and as commodities and services hit upon a well-funded demand. But it is mostly not the case when the measures for prevention and health promotion are unspecific. While stakeholders, as a rule, compete with one another for the scarce resources available in health sector, these proposals get only little sympathy of the providers of services. At the last, economic principles dominate in health policy over health aspects.

\section{Complexity}

Preventiveinterventions requirea complex and concerted approach including a myriad of intervention levels, intervention fields and stakeholders. Hence, stakeholders have to challenge their previous ways of acting and perceiving problems; often preventives measures are to be embedded in organisations and structural relations which, however, follow other goals sand incentivesystems. There arises a great need for coordination and adaptation which mostly overstrains the stakeholders. Therefore, probability for innovation blockades grows in direct relationship with the length of action chain required to implement preventive measures and thenumber of involved stakeholders with their heterogeneous interests.

The measures for prevention and health promotion which aim at bringing structural changes in conditions cannot be realised without experiencing great difficulties. The consequencefor measures targeting at reducing health inequities among other is that concepts which focus on individuals get priority over complex interventions to change work and life conditions. Hagen Kühn and Rolf Rosenbrock have distinguished these mechanisms with the formula of "Darwin law of prevention policy" ${ }^{24}$. Ac- 
cordingly in an effort to prevent diseases, different prevention policy measures competewith each other. Only such measures can be enforced most likely which are better adapted to social environment. Therefore, the chances for realisation of the interventions which prevent health risks at individual level (genetic disposition, health behaviour) are greater than complex interventions at societal level. The reasons are that individual level interventions in the form commodities and services can be comparatively easily commercialised and don't require touching societal and economical structures. M oreover, preferring the behavioural preventive approach has the appeal that it supports ideology according to which the individuals are liable for their health risks ("H ealthism").

\section{Conclusion}

In the first half of 1990s an extensive transformation process was initiated in health sector in Germany. Subsequently a number of regulatory instruments were deployed which aimed at creating cost-consciousness among stakeholders in $\mathrm{SH}$ I by thedelivery, financing and utilisation of health services. The German government, basically, conceived the stakeholders as egoistic subjects acting mere economically. This financial incentive system was combined with competition among both sickness funds and health care providers. However, the logic behind financial incentives and competition in $\mathrm{SHI}$ give rise to the apprehension that they mainly don't meet the expectations of a high quality and efficient health care and have brought undesirable counterproductive effects with them. M oreover, the instrument of financial incentives combined with various elements of privatisation the risk of sickness threatens $\mathrm{SHI}$ with erosion of the solidarity principle. In addition, as health sector regulation focuses mostly on the concept that stakeholders behave economic rationally, it fails to meet adequately other core challenges. This can be demonstrated, in particular, by using the example of prevention and health promotion politics.

The field of prevention and health promotion is dominated by economic interests, different views and logics in health policy to address the related issues, difficulties in providing evidence for unspe cific measures and less avoidable complexity of associated problems. Under these conditions, health policy inclines to redeem the complexity of the measures and outreach of the desired changes as well as to adapt them according to the power constellation among stakeholders.

The fact that the progressive privatisation of health care costs not only magnifies social inequalities but also health inequalities cannot be denied. A trend can be observed where prevention policy, under conditions prevailing in the last years in Germany, has dovetailed with the drafted paradigm shift of commercialisation and privatisation in health policy. It is the need of timethat health- and prevention policy in Germany backslides from this developed trend and once again concentrates on ensuring access to health and preventive services without any social discrimination. Nevertheless, such atrend reversal is currently neither in prevention policy nor in health policy to be observed. Initiatives in this direction would be most likely taken, if corresponding demands are formulated with emphasis in general public and the legitimation risks of "keep it up!" are appreciably increased for political elites. 


\section{References}

1. Busse R, Riesberg A. H ealth care systems in transition: Germany. Copenhagen: WHO Regional Office for Europe on behalf of the European Observatory on Health Systems and Policies; 2005.

2. Döhler M, Manow P. Strukturbildung von Politikfeldern. Das Beispiel bundesdeutscher Gesundheitspolitik seit den fünfziger Jahren. Opladen: Westdeutscher Verlag; 1997.

3. Gerlinger T. Zwischen Korporatismus und Wettbewerb: Gesundheitspolitische Steuerung im Wandel (Wissenschaftszentrum Berlin für Sozialforschung, Arbeitsgruppe Public Health, Discussion Paper P02-204). Berlin: WZB; 2002.

4. Stegmüller K. Wettbewerb im Gesundheitswesen - Konzeptionen zur "dritten Reformstufe" der Gesetzlichen Krankenversicherung. Frankfurt a.M .: VAS; 1996.

5. Rosenbrock R, Gerlinger T. Gesundheitspolitik. Eine systematische Einführung. Bern: H ans-Huber; 2006.

6. Hayek, FA von. Der Wettbewerb als Entdeckungsverfahren. In: Hayek, FA von. Tübingen: Freiburger Studien. p. 249-65

7. Winkelhake $O$, M iegel $U$, Thormeier K. Die personelle Verteilung von Leistungsausgaben in der Gesetzlichen Krankenversicherung 1998 und 1999. Konsequenzen für die Weiterentwicklung des deutschen Gesundheitswesens. Sozialer Fortschritt 2002, 51: 58-61.

8. Höppner $K$ et al. Grenzen und Dysfunktionalitäten des Kassenwettbewerbs in der GKV: Theorie und Empirie der Risikoselektion in Deutschland [Arbeitspapier $\mathrm{N} \mathrm{r}$. 4/2005]. Bremen: Universität Bremen, Zentrum für Sozialpolitik; 2005.

9. Greß S. Regulated Competition in Social Health Insurance: A Three-Country Comparison. International Social Security Review 2001; 59: 27-47.

10. Woolhandler S, Himmelstein D. Competition in a publicly funded healthcare system. British Medical Journal 2007; 335: 1126-1129.

11. Greß S, Stegmüller K. Gesetzliche Spielräume zur Entwicklung neuer Versorgungskonzepte - Eine systematische Analyse der einschlägigen Regelungen und deren Entwicklung. In: Amelung VE, Sydow J, Windeler A, eds. Vernetzung im Gesundheitswesen - Wettbewerb und Kooperation. Stuttgart: Kohlhammer; 2008. p. $91-102$.

12. Braun B. Rationierung und Vertrauensverlust im Gesundheitswesen - Folgen eines fahrlässigen U mgangs mit budgetierten Mitteln? St. Augustin: Asgard; 2000.

13. Gerlinger T. Soziale Ungleichheit von Gesundheitschancen: Anmerkungen zum Beitrag der Gesundheitspolitik [Diskussionspapier 2007-2]. Frankfurt a.M .: Johann Wolfgang Goethe-Universität Frankfurt, Institut für M edizinische Soziologie; 2007.

14. Simon M. Die Ökonomisierung des Krankenhauses. Der wachsende Einfluss ökonomischer Ziele auf patientenbezogene Entscheidungen [Discussion Paper P01205]. Berlin: Wissenschaftszentrum Berlin für Sozialforschung, Arbeitsgruppe Public Health; 2001.
15. Buhr P, Klinke S. Qualitative Folgen der DRG-Einführung für Arbeitsbedingungen und Versorgung im Krankenhaus unter Bedingungen fortgesetzter Budgetierung. Eine vergleichende Auswertung von vier Fallstudien [SP I 2006-311]. Berlin: Wissenschaftszentrum Berlin für Sozialforschung, Forschungsgruppe Public Health; 2006.

16. Pfaff $A B$, Busch $S$, Rindsfüßer $C$. Kostendämpfung in der gesetzlichen Krankenversicherung. Auswirkungen der Reformgesetzgebung 1989 und 1993 auf die Versicherten. Frankfurt a.M./New York: Campus; 1994.

17. Nink K, Schröder H. Ökonomische Aspekte des deutschen Arzneimittelmarktes 2005. In: Schwabe U, Paffrath D, eds. Arzneiverordnungs-Report 2006. Aktuelle Daten, Kosten, Trends und Kommentare. Berlin, Heidelberg: Springer; 2006. p. 182-244.

18. Newhouse J. Free for All? Lessons from the RAND $\mathrm{H}$ ealth Insurance Experiment. Cambridge: $\mathrm{H}$ arvard University Press; 1993.

19. Smedley BD, Syme SL, eds. Promoting Health. Intervention Strategies from Social and Behavioral Research. Washington, D.C.: Institute of M edicine; 2001.

20. Syme SL. Individuelle und gesell schaftliche Bestimmungsfaktoren für Gesundheit und Krankheit. In: Jahrbuch für Kritische M edizin 17: Rationierung der Medizin. Hamburg: Argument-Verlag; 1991. p. 91-111.

21. Rosenbrock R. Krankenkassen und Primärprävention - Anforderungen und Erwartungen an die Qualität. In: Walter U, Drupp M, Schwartz FW, eds. Prävention durch Krankenkassen - Zielgruppen, Zugangswege, Wirksamkeit und Wirtschaftlichkeit. Weinheim/M ünchen: Juventa; 2002. p. 40-57.

22. Van de Ven AH, Angle HL, Poole MS, eds. Research on the M anagement of Innovation: The M innesota Studies. New York: Harper \& Row; 1989.

23. Rogers EM. Diffusion of Innovations. $5^{\text {th }}$ ed. New York: Simon \& Schuster International; 2003.

24. Kühn H, Rosenbrock R. Präventionspolitik und $\mathrm{Ge}$ sundheitswissenschaften. In: Rosenbrock R, Kühn $H$, Köhler BM, eds. Präventionspolitik - Gesellschaftliche Strategien der Gesundheitssicherung. Berlin: edition sigma; 1994. p. 39-53.

Artigo apresentado em 16/01/2009

Aprovado em 02/02/2009 